\title{
A REVIEW ON THE SYNTHETIC METHODOLOGIES OF CHROMONES
}

\author{
MAHATHY VANGURU ${ }^{1}$, RAMCHANDER MERUGU ${ }^{1}$, SWETHA GARIMELLA ${ }^{1}$, LAXMINARAYANA E ${ }^{2 *}$
}

${ }^{1}$ Department ofBiochemistry, University College of Science and Informatics, Mahatma Gandhi University, Nalgonda, Telangana, India. ${ }^{2}$ Department of Science and Humanities, Sreenidhi Institute of Science and Technology, Hyderabad, Telangana, India. Email: elxnkits@yahoo.co.in

Received: 15 June 2018, Revised and Accepted: 18 July 2018

\section{ABSTRACT}

Chromones group of compounds and their derivatives form the essential component of pharmacophores in many biologically active molecules. They exhibit a wide range of biological activities such as antibiotic, antitumor, antiviral, antioxidant, antipsychotic, and antihypoxic activities. These applications have stimulated a continuous search for the synthesis of new compounds in this field and are being extensively investigated. The various methodologies so far reported for the synthesis of these compounds with the compounds biological applications are discussed in this communication

Keywords: Chromones, Synthesis, Biological activities.

(C) 2018 The Authors. Published by Innovare Academic Sciences Pvt Ltd. This is an open access article under the CC BY license (http://creativecommons. org/licenses/by/4. 0/) DOI: http://dx.doi.org/10.22159/ajpcr.2018.v11i12.27960

\section{INTRODUCTION}

Chromones and their structural analogs have motivated a great interest because of their usefulness as biologically active agents. The chromone moiety is the essential component of pharmacophores of a large number of bioactive molecules.<smiles>O=c1ccoc2ccccc12</smiles>

Chromone Nucleus

Chromone (1,4-benzopyrone) is a derivative of benzopyran with a substituted keto group on the pyran ring. Chromone, benzopyran, and coumarin possess a similar structure (Douglas et al., 2003) [1]. The first chromone to be used in pure form in clinical practice was Khellin extracted from the seeds of plant Ammi visnaga. Khellin was first prepared in impure form (Edwards and Howell, 2000) [2].

\section{SYNTHESIS}

Chromone may be synthesized under either acidic/basic conditions. The classical 2,3-disubstituted benzopyranone (c). Synthesis utilizes acidic conditions and is by far the most common method [3]. It proceeds through an intramolecular condensation of molecules such as (b), which are usually obtained through a Baker-Venkataraman rearrangement of compound (a), or through a Claisen ester condensation.

Jaen et al. [4] (1991) described the synthesis of novel type of [(aryl piperazinyl)alkoxy]-4H-1-benzopyran-4-ones.

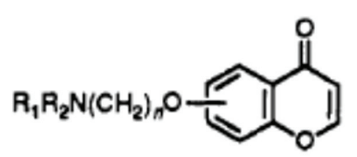

[(aryl piperazinyl)alkoxy]-4H-1-benzopyran-4-ones

Bass reported synthesis of chromones by cyclization of 2-hydroxyphenyl ketones with boron trifluoride-diethyl ether and methanesulfonyl chloride [5]. Bolos et al. [6] (1998) designed a series of novel 7-[3-(1-piperidinyl)propoxy]chromenones
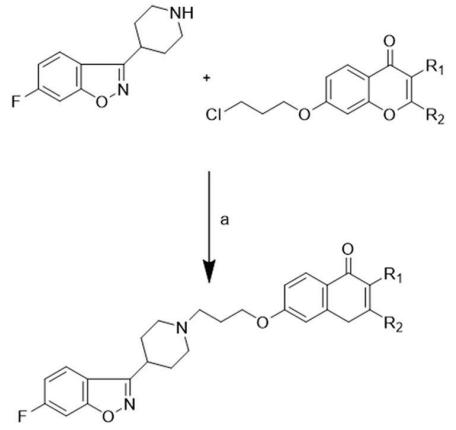

$$
\begin{aligned}
& \mathrm{a}=\mathrm{K}_{2} \mathrm{CO}_{3}, \mathrm{CH}_{3} \mathrm{CN} ; \text { Reflux } \\
& \mathrm{R}_{1}=\mathrm{R}_{2}=\mathrm{H} \\
& \mathrm{R}_{1}=\mathrm{CH}_{3}, \mathrm{R}_{2}=\mathrm{H} \\
& \mathrm{R}_{1}=\mathrm{CH}_{2} \mathrm{OH}, \mathrm{R}_{2}=\mathrm{H} \\
& \mathrm{R}_{1}=\mathrm{COOH}, \mathrm{R}_{2}=\mathrm{H} \\
& \mathrm{R}_{1}=\mathrm{H}, \mathrm{R}_{2}=\mathrm{CH}_{2} \mathrm{OH}
\end{aligned}
$$

Zhi et al. (2003) [7] synthesized 1,2-dihydro chromeno[3,4-f] quinoline derivatives.

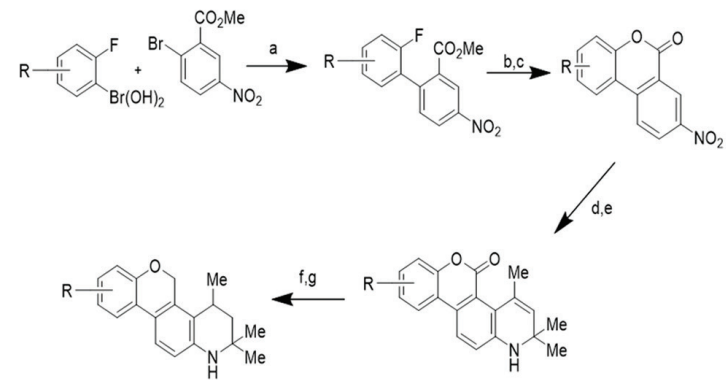

$$
\begin{aligned}
& \mathrm{a}=3 \mathrm{~mol} \% \mathrm{Pd}\left(\mathrm{PPh}_{3}\right)_{4}, \mathrm{Na}_{2} \mathrm{CO}_{3} \text {, Toluene/EtOH/ } / \mathrm{H}_{2} \mathrm{O} \\
& \text { Reflux, } 18 h, 90 \% \\
& b=\mathrm{NaOH}, \mathrm{THF}, \mathrm{rt}, 2 \mathrm{~h}, 95 \% \text {. } \\
& c=\mathrm{NaH}, \mathrm{DMF}, 80^{\circ} \mathrm{C}, 2 \mathrm{~h}, 85 \% \text {. } \\
& d=\mathrm{SnCl}_{2} \text {. AcOEt, Reflux, 2h, 95\% } \\
& \mathrm{e}=\text { Acetone, } 12 \text {, sealed tube } 130^{\circ} \mathrm{C}, 18 \mathrm{~h}, 50^{\circ} \\
& \mathrm{f}=\text { DIBAL-H, Toluene, }-40^{\circ} \mathrm{C}, 60-95 \% \\
& \mathrm{~g}=\mathrm{BF}_{3}-\mathrm{OEt}_{2}, \mathrm{Et}_{2} \mathrm{SiH}_{2} \mathrm{CH}_{2} \mathrm{Cl}_{2}, \mathrm{rt}, 2 \mathrm{~h}, 70-90 \%
\end{aligned}
$$


A new class of estrogen receptor beta (ER $\beta$ ) ligands based on the $6 \mathrm{H}$-chromeno [4,3-b] quinoline scaffold were reported by Vu et al. (2007) [8].

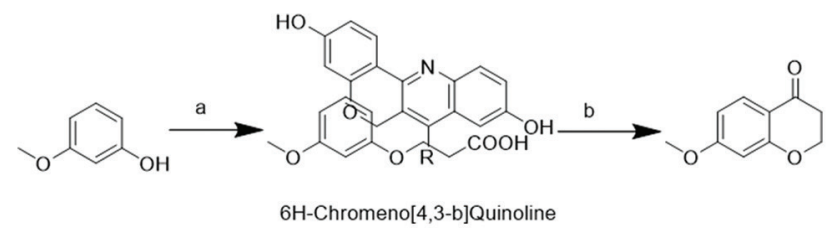

Yu et al. (2003) [9] reported synthesis of 3' R,4' R-Di-O-(-)-camphanoyl2',2'-dimethyl dihydro pyrano-[2,3-f]chromone on the basis of a structure-activity relationship study of 3' R,4' R-Di-O-(-)-camphanoyl(+)-cis-Khellactone and its analogs.

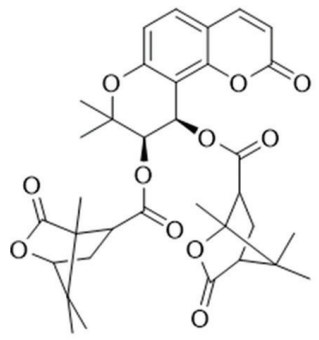

STRUCTURE OF DCK

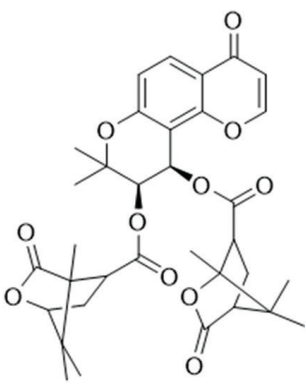

STRUCTURE OF DCP
Recanatini et al. (2001) [10] designed and synthesized chromone and xanthone derivatives.

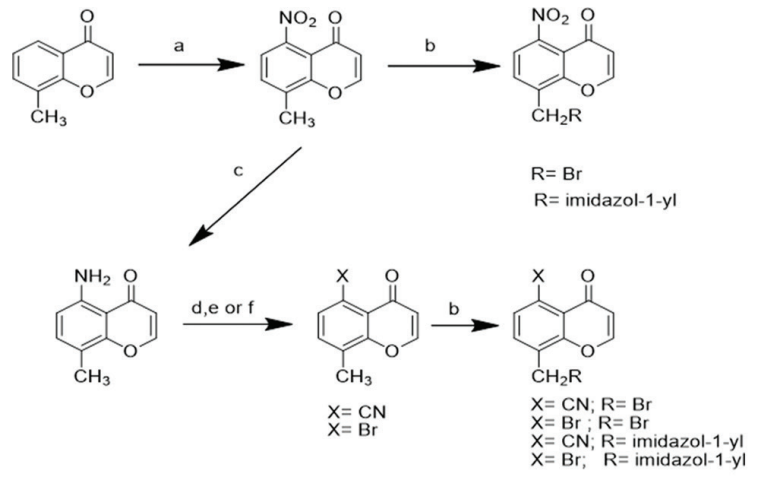

$\mathrm{a}=\mathrm{HNO} 3 / \mathrm{H} 2 \mathrm{SO} 4,0-5 \mathrm{Oc}$

$\mathrm{b}=\mathrm{N}$-bromosuccinimide, $\mathrm{CC1} 4$, reflux $5 \mathrm{~h}$

$\mathrm{c}=\mathrm{H} 2, \mathrm{Pd} / \mathrm{CaCO} 3$

$\mathrm{d}=\mathrm{NaNO} 2, \mathrm{HCl}, 0-50 \mathrm{C}$

$\mathrm{e}=\mathrm{NaCN} / \mathrm{CuCN}, 100 \mathrm{oC}, 20 \mathrm{~min}$

$\mathrm{f}=\mathrm{CuBr}, \mathrm{rt}, 12 \mathrm{~h}$

A new series of novel 2-vinyl chroman-4-ones (Albrecht et al., 2005) [11] were synthesized which were analogs of natural products aposphaerin $\mathrm{A}$ and $\mathrm{B}$.<smiles>[R]Oc1cc(CC([R])=O)c2c(c1[R20])OC(/C=C/CCC)CC2=O</smiles>

Aposphaerin A: $\mathrm{R}_{1}=\mathrm{R}_{2}=\mathrm{OH}, \mathrm{R}_{3}=\mathrm{Me}$ Aposphaerin B: $\mathrm{R}_{1}=\mathrm{OEt}, \mathrm{R}_{2}=\mathrm{R}_{3}=\mathrm{H}$
A new group of 2-phenyl naphthalene type structures of 11 $\mathrm{H}$-indolo[3,2-c] quinoline derivatives was designed by $\mathrm{He}$ et al. [12] (2003). Loaiza et al. [13] (2004) synthesized new 9-anilinothiazolo [5,4-b] quinoline derivatives. Guo et al. [14] (2009) synthesized a series of 5-alkoxy-[1,2,4]triazolo[4,3-a]quinoline derivatives.<smiles>CSc1nc2c(Nc3cc(N)cc(CO)c3)c3ccccc3nc2s1</smiles><smiles>[R]Oc1cc2nncn2c2ccccc12</smiles>

\section{5-Alkoxy-[1,2,4] Triazolo [4,3-a] quinoline derivative}

Shi et al. [15] (2008) synthesized substituted quinolines.<smiles>[R]Nc1cc(OC)c(Oc2cccc(C(F)(F)F)c2)c2c(C)ccnc12</smiles>

Pedram et al. [16] (2008) described the discovery of a new selective progesterone receptor modular which was the lead compound, 7,9-diflouro-5-(3-methyl cyclohex-2-enyl)-2,3,4-trimethyl-1,2-dihydro chromeno[3,4-f]quinoline

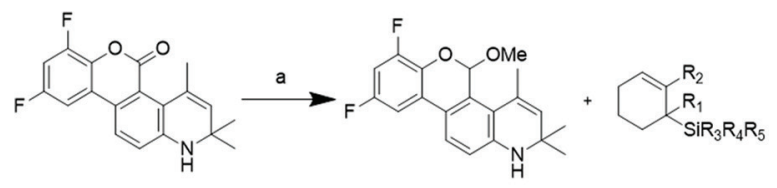

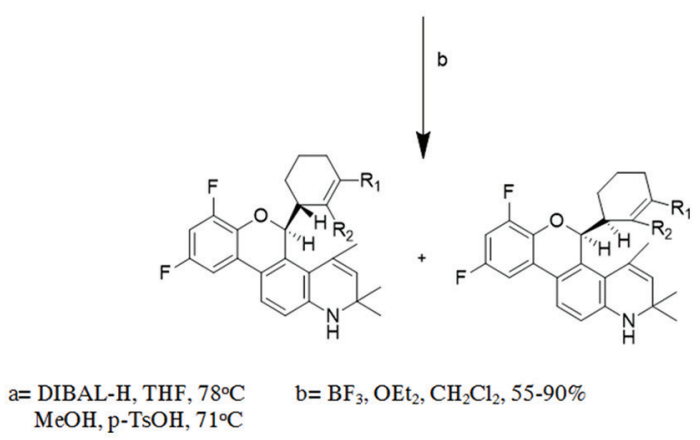

Nagaiah et al. (2010) [17] synthesized new cis-fused tetra hydro chromeno[4,3-b] quinolines by intramolecular [4+2] imino diels-alder reactions of 2-azadienes.

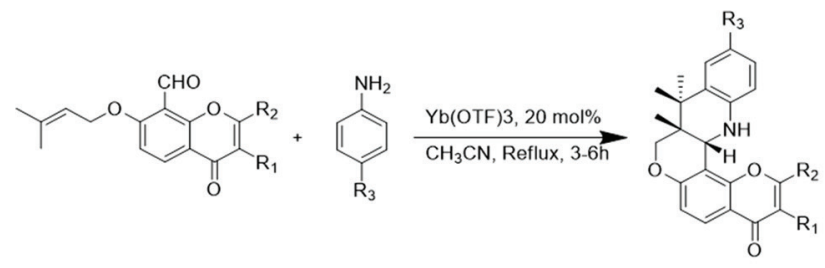

$R_{1}, R_{2}=H$, alkyl, aryl

3-Cis isomers only 
2,2-dimethyl-2H-chromone containing compounds were synthesized using microwave method by Zhou et al. [18] (2010)

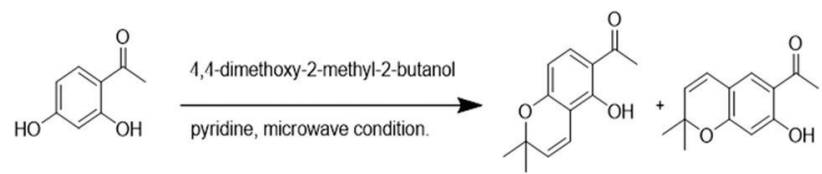

Ramesh and Nagarajan (2010) [19] synthesized chromenoquinolines through cyclization of different substituted anilines/naphthyl amine with O-Propargylated salicylaldehydes using $\mathrm{CuI} / \mathrm{La}(\mathrm{OTF})_{3}$ as a catalyst.

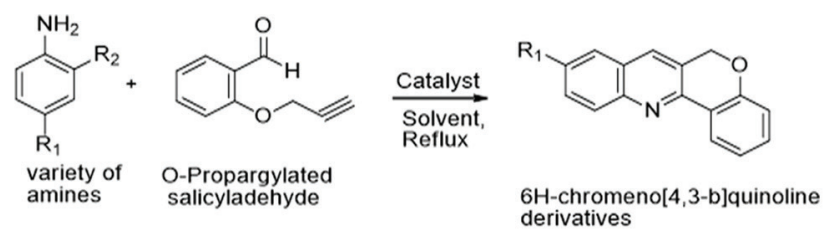

Prasad et al. (2011) [20] synthesized fused chromeno [4,3-b]quinolin-6-ones by ultrasound irradiation using 4-chloro-3-formyl coumarin. (Scheme 1)

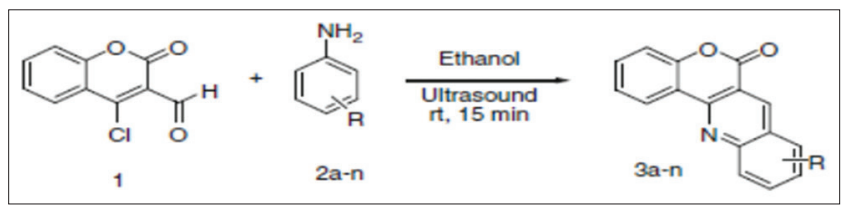

Scheme:1 Synthesis of fused chromeno-quinolines

Majumdar et al. (2011) [21] synthesized dihydro-3H-chromeno[3,4-b] [4,7]phenanthrolin-3-one and chromeno [4,3-b] pyrano [3,2-f]quinolin$3(13 \mathrm{H})$-one derivatives by aza Diels-Alder reaction. (Scheme 2)

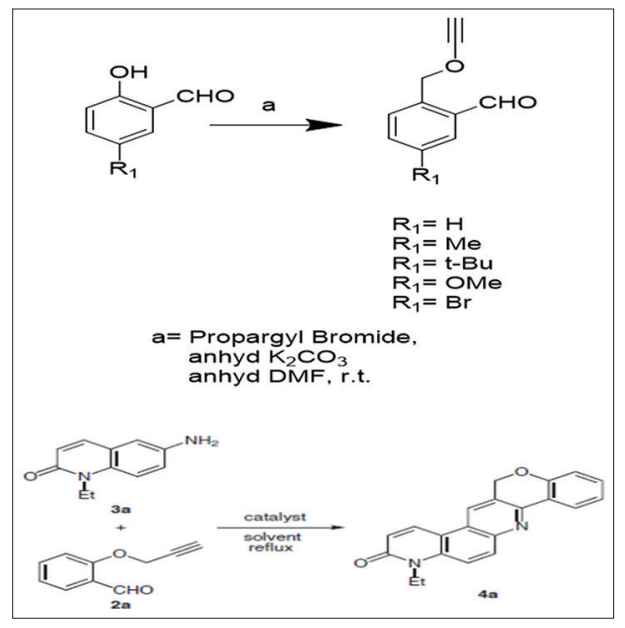

Scheme:2 Aza-Diels-Alder reaction

Synthesis of racemic 14-aryl-10,11,12,14-tetrahydro-9H-benzo[5,6]chromeno[2,3-b]quinoline-13-amines by Friedlander reaction of 3-amino-1-aryl-1H-benzo[f]chromene-2-carbonitriles with suitable cycloalkanones is described by Maalej et al. (2011) [22]
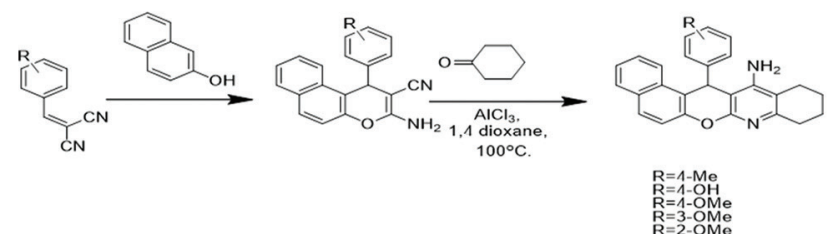

A one-pot intra molecular aza Diels-Alder approach for the synthesis of dihydrochromeno[4,3-b] pyrrolo [3,2-f]quinolines was reported by Ramesh and Nagarajan (2011) [23]
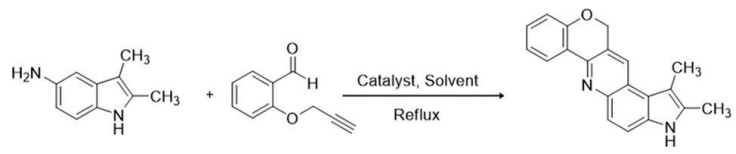

1,2-Dimethyl-3,12-dihydro chromeno[4,3-b]pyrrolo
$[3,2-$-flquinoline

Substituted chromones such as 5-hydroxy chromones with two aryl methyloxy substituent's were reported by Kim et al. (2011) [24]

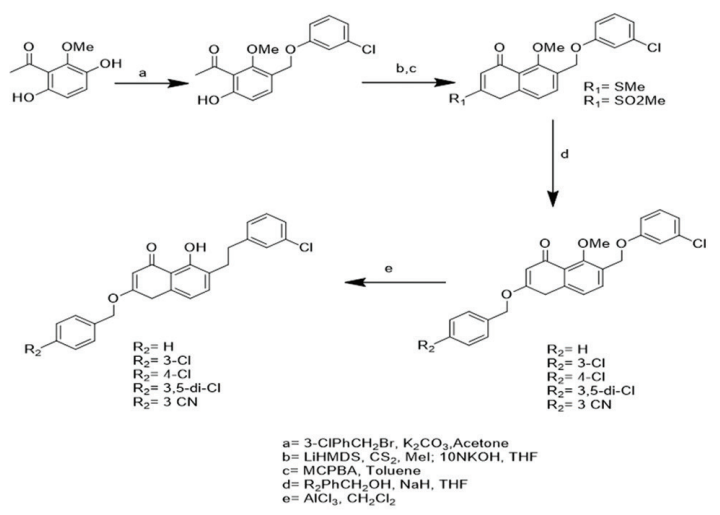

Motamedi et al. (2012) [25] combined silica sulfuric acid and sodium nitrite in the presence of wet $\mathrm{SiO}_{2}$ for the oxidative aromatization of novel tetrahydrochromeno[4,3-b] quinolines to their corresponding pyridine derivatives.

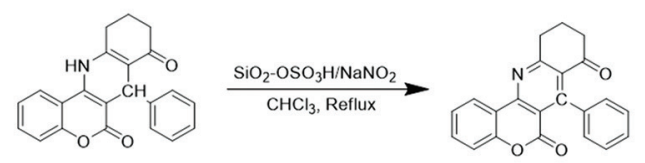

OXIDATIVE AROMATISATION OF TETRAHYDRO CHROMENO[4,3-b]QUINOLINES

Luniewski et al. [26] (2012) synthesized novel indolo-[2,3-b] quinoline derivatives substituted at N-6 and C-2 or C-9 positions with (di methyl amino) ethyl chains linked to heteroaromatic core by ether, amide or amine bonds.<smiles></smiles>

$$
\begin{aligned}
& \mathrm{R}_{1}=\mathrm{N}(\mathrm{Ts})(\mathrm{CH} 2)_{2} \mathrm{~N}(\mathrm{CH} 3)_{2} ; \mathrm{R}_{2}=\mathrm{H} \\
& \mathrm{R}_{1}=\mathrm{H} ; \mathrm{R}_{2}=\mathrm{N}(\mathrm{Ts})\left(\mathrm{CH}_{2}\right)_{2} \mathrm{~N}(\mathrm{CH} 3)_{2}
\end{aligned}
$$

Bedoya et al. [27] (2012) synthesized 18-quinoline-based compounds containing quinoline/tetrahydroquinoline rings.

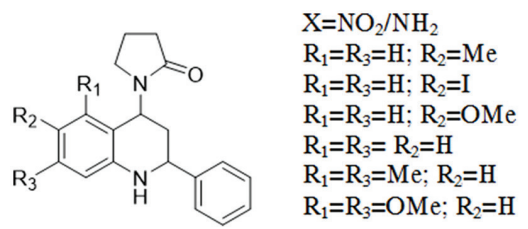


Godrey et al. [28] (2011) carried out Pd-mediated coupling for the synthesis of quinoline-oxazole hybrid compounds.
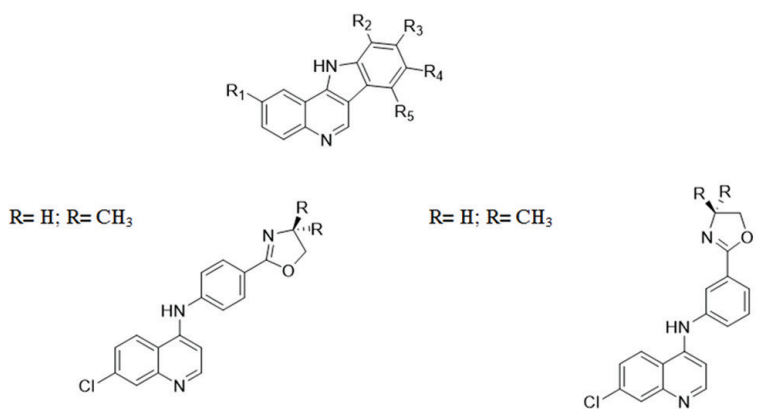

Bennardi et al. [29] (2008) carried out synthesis of substituted flavones and chromones using a Wells-Dawson heteropolyacid as a catalyst.

$$
\begin{array}{ll}
\text { Toluene or } \\
\text { Solvent free } \\
\text { Ar = Phenyl } \\
\text { Furyl } \\
\text { 1-Naphthyl } \\
\text { 2-Naphthyl }
\end{array}
$$

Dengle et al. [30] (2013) carried out synthesis and antimicrobial evaluation of chromones bearing
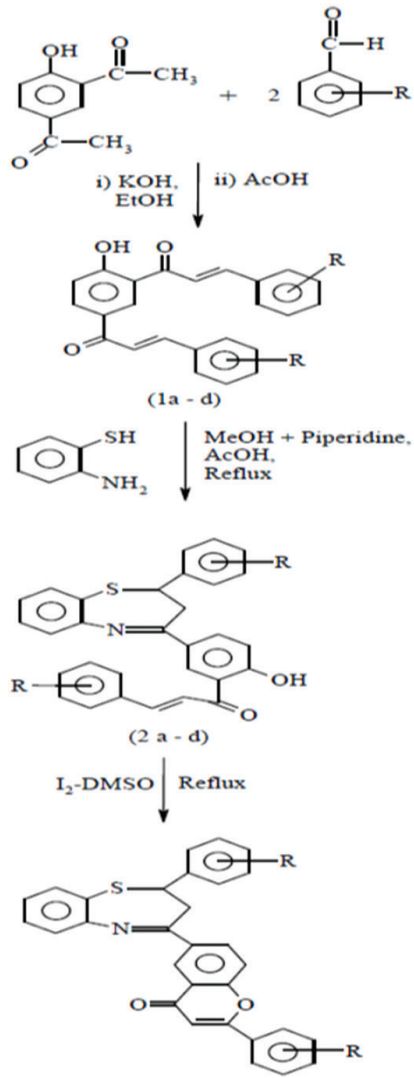

Where, $\mathrm{R}=\mathrm{H}, \mathrm{CH}_{3}, \stackrel{(3 \mathrm{a}-\mathrm{d})}{\mathrm{OCH}}, \mathrm{Cl}$

1, 5 -benzo thiazepinyl moiety.

Suryanarayana and Anuradha [31] (2013) reported that new series of hetroannulated chromene-9-carbonitrile derivatives have been synthesized from 4-diazobicyclo [2, 2, 2]-octane catalyzed BaylisHillmann reaction of diversely substituted 7-hydroxy-8-formyl-2furylchromones under a nitrogen atmosphere at room temperature in good yields.

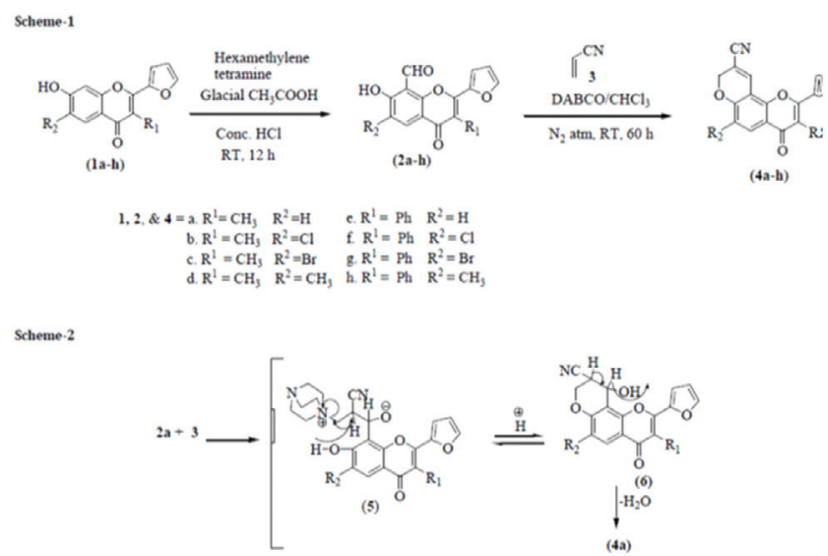

Yanhui Guo et al. [32] (2017) reported the reactions between $o$-hydroxylphenyl-functionalized enaminones and sulfonyl hydrazines providing 3-sulfenylated chromones through domino chromone ring construction and $\mathrm{C}\left(\mathrm{sp}^{2}\right)-\mathrm{H}$ bond sulfenylation has been achieved under transition-metal-free conditions using $\mathrm{KIO}_{3}$ as the only catalyst. Tetsuya Eguchi and Yukio Hoshino [33] (2001) reported chromones regioselectivity reduced to $2 \mathrm{H}$-1-benzopyrans through the 1, 2-addition of 9-borabicyclo-[3.3.1] nonane.

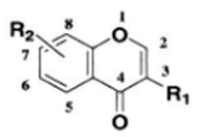

1
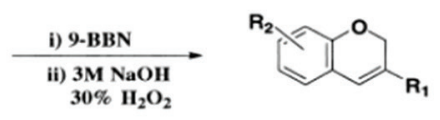

2

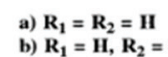

b) $R_{1}=H, R_{2}=6-0 M$ c) $R_{1}=H, R_{2}=6-P h$ d) $R_{1}=H, R_{2}=6-M c$ c) $\mathrm{R}_{1}=\mathrm{H}, \mathrm{R}_{2}=6-\mathrm{Cl}$ D) $R_{1}=\mathrm{H}, \mathbf{R}_{2}=6-\mathrm{NO}_{2}$
g) $\mathbf{R}_{1}=\mathrm{H}, \mathbf{R}_{2}=7-0 \mathrm{OM}$

Scheme 1

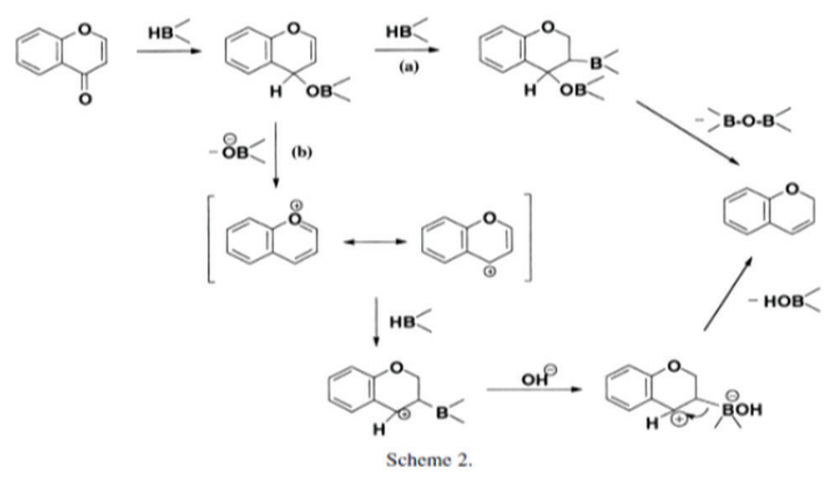

Ibrahim et al. [34] (2017) presented a review which discusses the methods developed for the synthesis and reactions of 2-aminochromone-3- carboxaldehydes. 

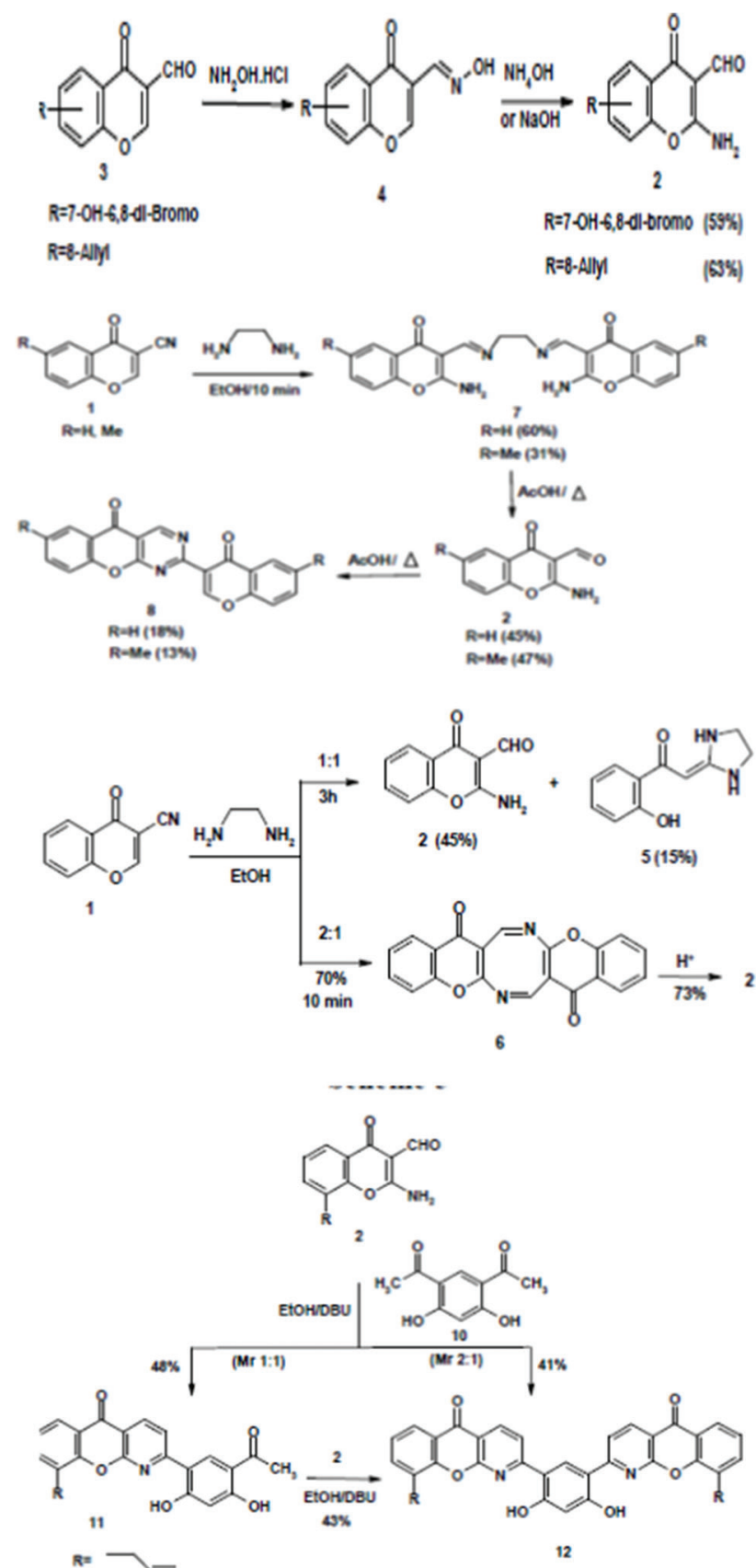

Santosh [35] (2014) reported the process for the preparation of chromones, isoflavones, and homoisoflavones using vilsmeier reagent generated from phthaloyl dichloride and DMF.
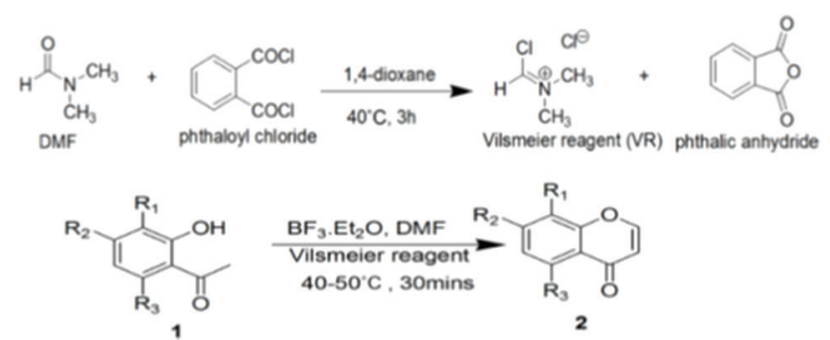

Engelhart et al. [36] (2013) reported the synthesis of chromone, quinolone, and benzoxazinone sulfonamide nucleosides as conformationally constrained inhibitors of adenylating enzymes required for siderophore biosynthesis.
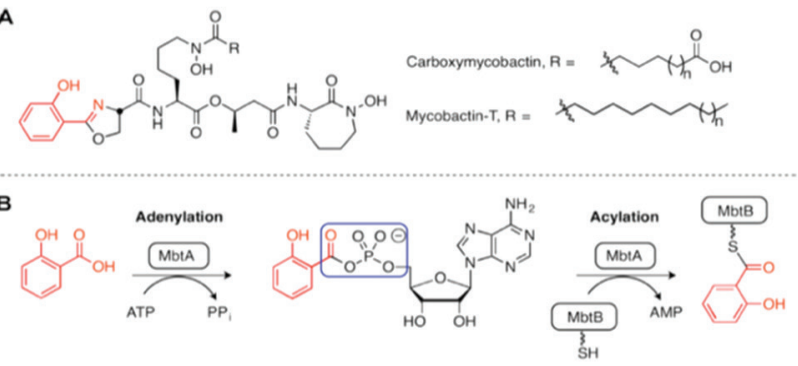

C

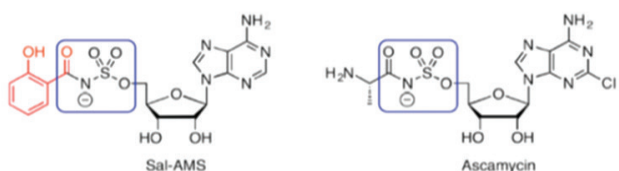

Chen et al. [37] (2017) reported that a concise and environmentfriendly route for the synthesis of multisubstituted chromone-fused bicyclic pyridine compounds through one-step reaction of chromone3 -carboxaldehyde $\mathbf{1}$ and $N$-benzyl nitro ketene aminals (NBNKAs, 2) in ethanol media has been developed.<smiles>O=Cc1coc2ccccc2c1=O</smiles>

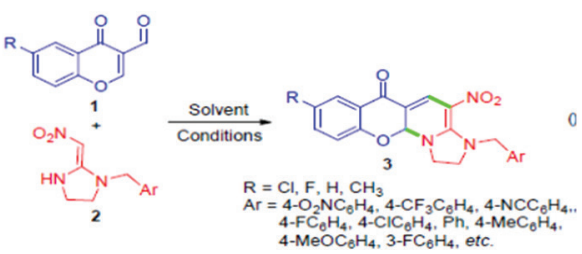

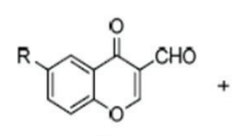

1

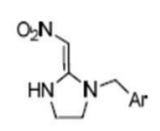

2

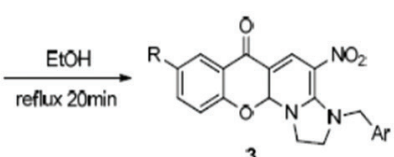

Gang Cheng et al. [38] (2017) developed an efficient synthesis of azachromones from 3-iodo-4-(1H)-pyridones and terminal acetylenes through a cascade carbonylation-Sonogashira-cyclization reaction. By controlling the use of bases, both 6-aza-chromones 5 and 3-(4-oxo1,4-dihydroquinoline-3-carbonyl)-4H-pyrano[3,2-c]quinolin-4-ones 6 could be selectively obtained in moderate to good yields.

Patel et al. [39] (2011) reported that novel (3E)-3-[[4-(Aryl or Alkyl sulfonyl, Aryl carbonyl and Heteroaryl) piperazin-1-yl]methylene] chroman-4-one and N-[1-(Aryl or Alkyl sulfonyl, Aryl carbonyl and Heteroaryl) -4-piperidyl]-6-methyl-4-oxo-chromene-3-carboxamide was synthesized and antibacterial good activity against the bacterial strains. 


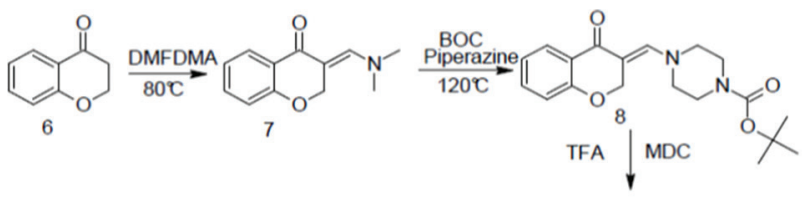<smiles>[R]N1CCN(/C=C2\COc3ccccc3C2=O)CC1</smiles>

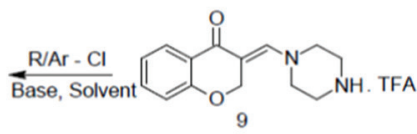

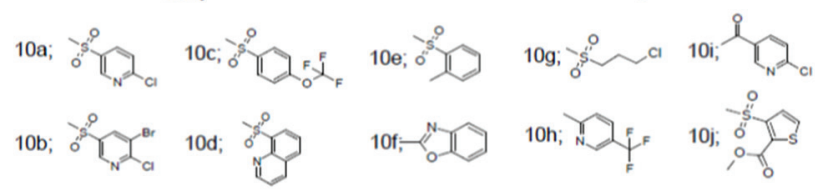

Talhi et al. [40] (2016) reported a one-pot synthesis of novel benzopyran-4-ones is organo base-catalyzed Michael addition on chromone-3-carboxylic acid led to decarboxylation and pyran-4-one ring opening of the latter. This was followed by chromone - and/or chromanone ring closure of the resulting Michael adducts when R1 is an ortho-hydroxyaryl group.
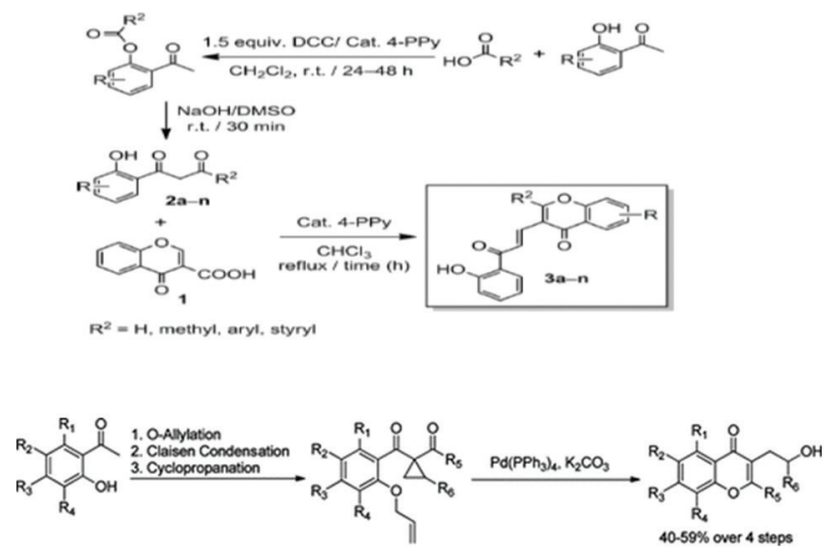

A tandem deprotection-cyclization reaction of 1,1-diacylcyclopropanes is described which allows rapid access to structurally diverse 2,3-disubstituted chromones in good yields, and with straightforward purification. The utility of this reaction is showcased by the construction of the potent antibacterial marine natural product bromophycoic acid $\mathrm{E}$ scaffold (Robert et al., 2017) [41].

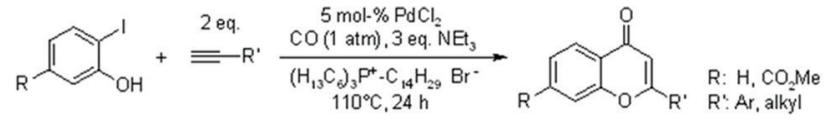

A highly efficient and selective palladium-catalyzed ligand-free cyclocarbonylation reaction of $o$-iodophenols with terminal acetylenes under atmospheric CO pressure affords diversified chromones in very good yields [42]. The use of a phosphonium salt ionic liquid as the reaction medium enhances the efficiency of the cyclocarbonylation reaction.

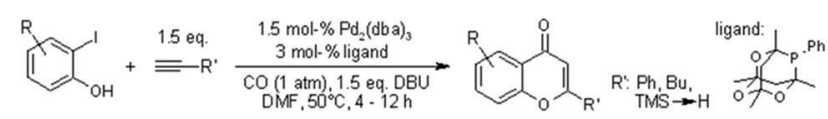

A palladium complex of 1,3,5,7-tetramethyl-2,4,8-trioxa-6-phenyl-6phosphaadamantane is an effective catalyst for a sequential microwaveassisted Sonogashira and carbonylative annulation reaction to give substituted flavones [43].

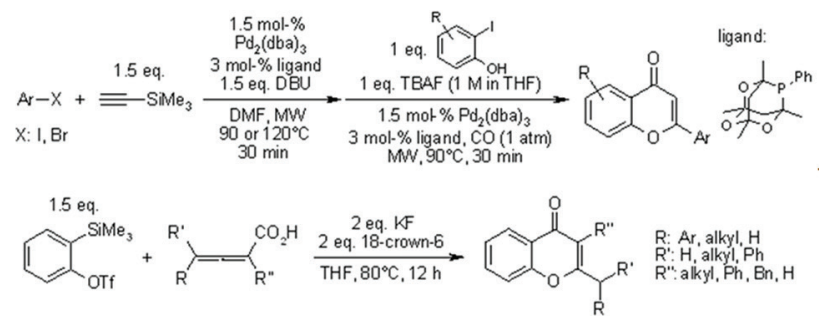

Chromone derivatives were synthesized from 2,3-allenoic acids and benzynes in good yields under mild conditions. The benzyne intermediate undergoes 1,2-addition with the carbonyl group, followed by ring opening, conjugate addition, and protonolysis to afford chromone derivatives. This protocol allows the diversity due to the substituent-loading capability of 2,3-allenoic acids as well as benzynes [44].

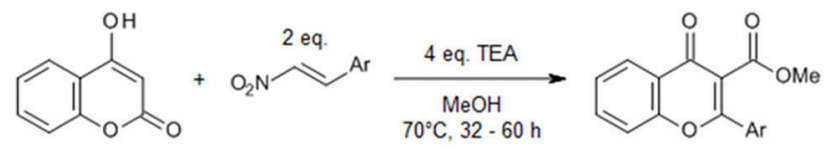

The unusual alcohol-mediated reaction of 4-hydroxycoumarins and $\beta$-nitroalkenes leads to 4-oxo-2-aryl-4H-chromene-3-carboxylate (flavone-3-carboxylate) derivatives. The transformation occurs through the in situ formation of a Michael adduct, followed by the alkoxide ion mediated rearrangement of the intermediate. The effects of different media on the reaction were investigated [45].

A Pd-catalyzed copper-free carbonylative Sonogashira coupling reaction at room temperature was achieved using water as a solvent under balloon pressure of $\mathrm{CO}$ with $\mathrm{Et}_{3} \mathrm{~N}$ as a base [46]. The developed method was successfully applied to the synthesis of flavones.

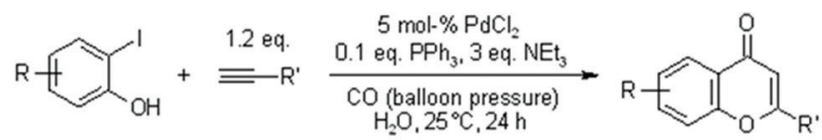

A mild ICl-induced cyclization of heteroatom-substituted alkynones provides a simple, highly efficient approach to various 3 -iodochromones, iodothiochromenones, iodoquinolinones, and analogs in good to excellent yields. Subsequent palladium-catalyzed transformations afford a rapid increase in molecular complexity [47].
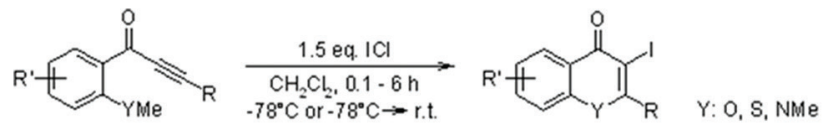

Apart from the above, cytotoxicity studies of 2-vinylchromone derivatives on human breast cancer cell lines were also investigated for their biological activity [48]. Endophytic fungi seem to be a major resource for naturally occurring chromones [49-51].

Chromones group of compounds and their derivatives form the essential component of pharmacophores in many biologically active molecules. They exhibit a wide range of biological activities such as antibiotic, antitumor, antiviral, antioxidant, antipsychotic, and antihypoxic activities. These applications have stimulated a continuous search for the synthesis of new compounds in this field and are being extensively investigated.

\section{AUTHOR'S CONTRIBUTION}

MV and SG conceived the present idea and collected literature about chromones. RM and EL developed and analyzed the collected literature. 
MV and SG wrote the manuscript in consultation with RM and EL. RM and EL supervised the work and discussed the final draft and contributed to the final manuscript.

\section{CONFLICTS OF INTEREST}

The authors declare that they have no conflicts of interest

\section{REFERENCES}

1. Horton DA, Bourne GT, Smythe ML. The combinatorial synthesis of bicyclic privileged structures or privileged substructures. Chem Rev 2003;103:893-930.

2. Edwards AM, Howell JB. The chromones: History, chemistry and clinical development. A tribute to the work of Dr. R.E.C. Altounyan. Chem Exp Allergy 2000;30:756-74.

3. Miao H, Yang Z. Regiospecific carbonylative annulation of iodophenol acetates and acetylenes to construct the flavones by a new catalyst of palladium-thiourea-dppp complex. Org Lett 2000;2:1765-8.

4. Jaen JC, Wise LD, Heffner TG, Pugsley TA, Meltzer LT. Dopamine autoreceptor agonists as potential anti-psychotics. J Med Chem 1991;34:248-56.

5. Bass RJ. Synthesis of chromones by cyclization of 2-hydroxyphenyl ketones with boron trifluoride-diethyl ether and methanesulphonyl chloride. J Chem Soc Chem Commun 1976;2:78-9.

6. Bolos J, Anglada L, Gubert S, Planas JM, Agut J, Princep M, et al. Ortiz. 7-[3-(1-piperidinyl) propoxy]chromenones as potential antipsychotics. J Med Chem 1998;41:5402-9.

7. Zhi L, Ringgenberg JD, Edwards JP, Tegley CM, West SJ, Pio B, et al. Development of progesterone receptor antagonists from 1,2-dihydrochromeno[3,4-f]quinoline agonist pharmacophore. Bioorg Med Chem Lett 2003;13:2075-8.

8. Vu AT, Campbell AN, Harris HA, Unwalla RJ, Manas ES, Mewshaw RE. ER $\beta$ ligands Part 6: $6 \mathrm{H}$ - chromeno[4,3-b]quinolines as a new series of estrogen receptor $\beta$-selective ligands. Bioorg Med Chem Lett 2007; 17:4053-6.

9. Yu D, Brossi A, Kilgore N, Wild C, Allaway G, Lee KH, et al. Anti-HIV agents. Part 55: 3'R,4'R-di-(O)-(-)-camphanoyl-2',2'dimethyldihydropyrano[2,3-f]chromone (DCP), a novel anti-HIV agent. Bioorg Med Chem Lett 2003;13:1575-6.

10. Recanatini M, Bisi A, Cavalli A, Belluti F, Gobbi S, Rampa A, et al. A new class of non-steroidal aromatase inhibitors: Design and synthesis of chromone and xanthone derivatives and inhibition of the P 450 enzymes aromatase and 17 $\alpha$-Hydroxylase/C 17,20-Lyase. J Med Chem 2001;44:672-80

11. Albrecht U, Lalk M, Langer P. Synthesis and structure-activity relationships of 2-vinyl chroman-4-ones as potent antibiotic agents. Bioorg Med Chem Lett 2005;13:1531-6.

12. He L, Chang HX, Chou TC, Savaraj N, Cheng CC. Design of antineoplastic agents based on the 2-phenyl naphthalene type structural pattern synthesis and biological activity studies of 11H-Indolo [3, 2-c] quinoline derivatives. Eur J Med Chem 2003;38:101-7.

13. Rodriguez-Loaiza P, Quintero A, Sotres RR, Solano JD, Lira-Rocha A. Synthesis and evaluation of 9-anilinothiazolo [5,4-b] quinoline derivatives as potential anti tumorals. Eur J Med Chem 2004;39:5-10

14. Guo LJ, Wei CX, Jia JH, Zhao LM, Quan ZS. Design and synthesis of 5-alkoxy-[1,2,4]triazolo[4,3-a]quinoline derivatives with anticonvulsant activity. Eur J Med Chem 2009;44:954-8.

15. Shi A, Nguyen TA, Battina SK, Rana S, Takemoto DJ, Chiang PK, et al. Synthesis and anti-breast cancer activities of substituted quinolines. Bioorg Med Chem Lett 2008;18:3364-8.

16. Pedram B, van Oeveren A, Mais DE, Marschke KB, Verbost PM, Groen $\mathrm{MB}$, et al. A tissue-selective nonsteroidal progesterone receptor modulator: 7,9-difluoro-5-(3-methylcyclohex-2-enyl)-2,2,4-trimethyl1,2-dihydrochromeno[3,4-f]quinoline. J Med Chem 2008;51:3696-9.

17. Nagaiah K, Venkatesham A, Rao RS, Saddanapu V, Yadav JS, Basha SJ, et al. Synthesis of new cis-fused tetrahydrochromeno [4,3-b]quinolines and their antiproliferative activity studies against MDA-MB-231 and MCF-7 breast cancer cell lines. Bioorg Med Chem Lett 2010;20:3259.

18. Zhou T, Shi Q, Lee KH. Efficient microwave-assisted one-pot preparation of angular 2,2-dimethyl-2H-chromone containing compounds. Tetrahedron Lett 2010;51:4382-6.

19. Ramesh S, Nagarajan VR. A flexible approach to the chromeno quinolines under copper/lewis acid catalysis. Syn Lett 2010;5:757-60.

20. Prasad VJ, Reddy JS, Kumar NR, Solomon KA, Krishna GG. An efficient ultra sound promoted catalyst-free protocol for the synthesis of chromeno [4,3-b]quinolin-6-ones. J Chem Sci 2011;123:673-9.

21. Majumdar KC, Ponra S, Taher A. Dihydro-3H-chromeno[3,4-b][4,7] phenanthrolin-3-one and chromeno[4,3-b]pyrano[3,2-f]quinolin$3(13 \mathrm{H})$-one derivatives by aza-diels-alder reaction. Synthesis 2011;3:463-8

22. Maalej E, Chabchoub F, Samadi A, de los Ríos C, Perona A, Morreale A, et al. Synthesis, biological assessment and molecular modeling of 14-aryl-10,11,12,14-tetrahydro-9H-benzo[5,6] chromeno[2,3-b]quinolin-13-amines. Bioorg Med Chem Lett 2011;21:2384-8.

23. Ramesh S, Nagarajan R. Synthesis of Di hydro chromeno[4,3-b] pyrrolo[3.2-f]quinolines via intramolecular aza diels-alder reaction. Tetrahed Lett 2011;52:4857-60.

24. Kim MK, Yu MS, Park HR, Kim KB, Lee C, Cho SY, et al. 2, 6-Bis-aryl methyloxy-5-Hydroxy chromones with anti-viral activity against both hepatitis $\mathrm{C}$ virus (HCV) and SARS associated coronavirus(SCV). Eur J Med Chem 2011;46:5698-704.

25. Luniewski W, Wietrzyk J, Godlewska J, Switalska M, Piskozub M, Peczynska-Czoch W, et al. New derivatives of 11-methyl-6-[2-(dimethyl amino) ethyl]-6H-indolo [2,3-b]quinoline as cytotoxic DNA topoisomerase 2 inhibitors. Bioorg Med Chem Lett 2012;22:6103-7.

26. Bedoya LM, Abad MJ, Calonge E, Saavedra LA, Gutierrez C M, Kouznetsov VV, et al. Quinoline-based compounds as modulators of HIV transcription through NF-kappaB and sp1 inhibition. Antiviral Res 2010;87:338-44.

27. Motamedi R, Sarvatahevabadi M, Rezaei MR. Oxidative aromatization of novel tetrahydrochromeno[4,3-b]quinolines using silica sulfuric acid/NaNO . Arab J Chem 2012;10(1):1-4.

28. Bennardi DO, Romanelli GP, Jios JL, Autino JC, Baronetti GT, Thomas HJ. ChemInform Abstract: Efficient Microwave Solvent-Free Synthesis of Flavones, Chromones, Coumarins and Dihydrocoumarins. ARKAT USA Inc., 2008;11:123-30.

29. Gordey EE, Yadav PN, Merrin MP, Davies J, Ward SA, Woodman GM, et al. Synthesis and biological activities of 4-N-(anilinyl-n-[oxazolyl])7-chloroquinolines ( $\mathrm{n}=3$ '/4') against Plasmodium falciparum in in vitro models. Bioorg Med Chem Lett 2011;21:4512-5.

30. Dengle RV, Deshmukh RN. Synthesis and antimicrobial evaluation of chromones bearing 1, 5-benzo thiazepinyl moiety. Inter J Pharml Sci Res 2013;4(4):1495-8.

31. Venkata S, Anuradha V. An efficient synthesis of hetroannulated chromene-9-carbonitrile derivatives via Baylis-Hillmann reaction. Int J Curr Pharm Res 2013;5(3):36-9.

32. Dengle RV, Deshmukh RN. Synthesis and antimicrobial evaluation of chromones bearing 1,5-benzothiazepine moiety. In J Pharm Sci Res 2013;4:1495-8.

33. Ch VS, Anuradha V. An efficient synthesis of hetroannulated chromene9-carbonitrile derivatives via baylis-hillmann reaction. Int J Curr Pharm Res 2013;5:36-9.

34. Guo Y, Zhong S, Wei L, Wan JP. Transition-metal-free synthesis of 3-sulfenylated chromones via $\mathrm{KIO}_{3}$-catalyzed radical $\mathrm{C}\left(\mathrm{sp}^{2}\right)-\mathrm{H}$ sulfenylation. Beilstein J Org Chem 2017;13:2017-22.

35. Eguchi T, Hoshino Y. Synthesis of $2 \mathrm{H}$-chromenes through the reduction of chromones with 9-BBN. Chem Soc Jpn 2001;74:967-70.

36. Ibrahim MA, El-Gohary MM, Badran S, Hashiem SH. Synthesis and reactivity of 2-aminochromone-3- carboxaldehydes towards nucleophilic reagents. J Pharm Appl Chem 2017;3:83-92.

37. Yadav SK. Process for the preparation of chromones, isoflavones and homoisoflavones using vilsmeier reagent generated from phthaloyl dichloride and DMF. Int J Organic Chem 2014;4:236-46.

38. Engelhart CA, Aldrich CC. Synthesis of chromone, quinolone, and benzoxazinone sulfonamide nucleosides as conformationally constrained inhibitors of adenylating enzymes required for siderophore biosynthesis. J Org Chem 2013;78:7470-81.

39. Liang C, Baoqu W, Yucheng Z, Shengjiao Y, Jun L. Synthesis of multisubstituted chromone-fused bicyclic pyridine compounds. Chin J Org Chem 2017;37:1433-42.

40. Cheng G, Qi Y, Zhou X, Sheng R, Hu YZ, Hu Y. Synthesis of 6-azachromone derivatives through cascade carbonylation-sonogashiracyclization. Sci Rep 2017;7:4398.

41. Patel MC, Nilesh NG, Rajani DP. Synthesis and characterization of some novel chromones and chromanones derivatives and its biological screening. Pharm Chem 2011;3:422-32

42. Talhi O, Brodziak-Jarosz L, Panning J, Orlikova B, Zwergel C, Tzanova $\mathrm{T}$, et al. Synthesis of benzopyran-4-ones with cancer preventive and therapeutic potential. Eur J Org Chem 2016;5:965-75. 
43. Smith RJ, Nhu D, Clark MR, Gai S, Lucas NT, Hawkins BC. Synthesis of chromones from 1,1-diacylcyclopropanes: Toward the synthesis of bromophycoic acid E. J Org Chem 2017;82:5317-27.

44. Yang Q, Alper H. Synthesis of chromones via palladium-catalyzed ligand-free cyclocarbonylation of o-iodophenols with terminal acetylenes in phosphonium salt ionic liquids. J Org Chem 2010;75:948-50.

45. Awuah E, Capretta A. Access to flavones via a microwave-assisted, one-pot sonogashira-carbonylation-annulation reaction. Org Lett 2009;11:3210-3

46. Chai G, Qiu Y, Fu C, Ma S. Efficient assembly of chromone skeleton from 2,3-allenoic acids and benzynes. Org Lett 2011;13:5196-9.

47. Zanwar MR, Raihan MJ, Gawande SD, Kavala V, Janreddy D, Kuo $\mathrm{CW}$, et al. Alcohol mediated synthesis of 4-Oxo-2-aryl-4H-chromene- 3-carboxylate derivatives from 4-hydroxycoumarins. J Org Chem 2012;77:6495-504

48. Liang B, Huang M, You Z, Xiong Z, Lu K, Fathi R, et al. Pd-catalyzed copper-free carbonylative sonogashira reaction of aryl iodides with alkynes for the synthesis of alkynyl ketones and flavones by using water as a solvent. Org Chem 2005;70:6097-100

49. Zhou C, Dubrovsky AV, Larock RC. Diversity-oriented synthesis of 3-iodochromones and heteroatom analogues via ICL-induced cyclization chengxiang. J Org Chem 2006;71:1626-32.

50. Swati K, Megha R, Seema B. Docking and cytotoxicity studies of 2-vinylchromone derivatives on human breast cancer cell lines. Int J Pharm Pharm Sci 2015;1:113-7.

51. Dilip FA, Kumar TR. Endophytic fungi: treasure for anti-cancerous compounds. Int J Pharm Pharm Sci 2016;1:35-42. 